\title{
Effect of Cattle Manure on Young Plants of Khaya senegalensis Submitted to Different Irrigation Intervals
}

\author{
Alessandro Almeida Mendes \\ Forest Engineering self-governing researcher, Vitória da Conquista, Bahia, Brazil \\ E-mail: leocap250@gmail.com
}

Paulo Araquém Ramos Cairo (Corresponding Author)

Departament of Crop and Animal Science, Sowthwest Bahia State University, Vitória da Conquista, Bahia, Brazil

E-mail: pcairo@uol.com.br

Tande Caires Leite

Forest Engineering self-governing researcher, Vitória da Conquista, Bahia, Brazil E-mail: tcleite96@gmail.com

\section{Vinicius Vieira Botelho}

Forest Engineering self-governing researcher, Vitória da Conquista, Bahia, Brazil E-mail: vinimeira18@outlook.com

Janaína Ramos de Jesus Silva

Agronomist Engineering self-governing researcher, Vitória da Conquista, Bahia, Brazil E-mail: janaaramos@hotmail.com

Raul Antônio Araújo do Bonfim

Sowthwest Bahia State University, Vitória da Conquista, Bahia, Brazil

E-mail: raularaujoraul@gmail.com 


\author{
Mateus Pires Barbosa \\ Sowthwest Bahia State University, Vitória da Conquista, Bahia, Brazil \\ E-mail: mateus_pbarbosa@ hotmail.com
}

\author{
Received: Sep. 19, 2019 \\ Accepted: Oct. 10, 2019 \\ Published: Oct. 11, 2019 \\ doi:10.5296/jas.v8i1.15475 \\ URL: https://doi.org/10.5296/jas.v8i1.15475
}

\begin{abstract}
This study aimed to evaluate the effect of cattle manure on young plants of Khaya senegalensis submitted to different irrigation intervals. A greenhouse experiment was carried out during 2017 cold season, based in a $5 \times 3$ factorial arrangement - cattle manure fertilizing with 0,10, 20, 30 and 40\% doses, and 3-day, 6-day and 12-day irrigation intervals. Water potential, relative water content (RWC), water consumption (WC), water use efficiency (WUE), chlorophyll content estimation (SPAD index), plant height, stem diameter, plant total dry mass and free amino acid and proline content were measured. Irrigation intervals had no significant effect on physiological traits and plant water relationships, except for WUE, which was higher under 12-day irrigation interval. This was assumed as an indication of non-occurrence of water stress, even under the longest irrigation interval. Cattle manure, in turn, played a significant effect on these traits, except for water potential, irrespective of irrigation intervals. Increasing cattle manure doses improved RWC (just doses up to 20\%), reduced WC and increased WUE, SPAD index, and both free amino acid and proline contents. On the other hand, growth-related parameters were not affected by cattle manure, but a significant effect of irrigation intervals was observed. Both plant height and total dry mass were lower under 3-day and 6-day irrigation intervals. We suspect a possibly low evapotranspiration, given the relatively low temperatures of that season $\left(14-16^{\circ} \mathrm{C}\right)$, which may have reduced the demand for irrigation in the experimental period. Thus, soil moisture under the shorter irrigation intervals may have increased until reach to a close to saturation level, limiting the amount of soil oxygen and hampers nutrient uptake.
\end{abstract}

Keywords: woody plants, water stress, organic fertilizing

\title{
1. Introduction
}

African mahogany stands out in the noble wood market and is referred one of the most valuable tropical woody species in the world (Nikiema and Pasternak, 2008). Khaya senegalensis is the African mahogany species most cultivated in Brazil, due to its rusticity and relative adaptability for cultivation under adverse conditions, especially in low rainfall regions (Pinheiro et al., 2011).

Water is one of the most limiting abiotic factor for plants, since its availability reflects on 
many morphological and physiological features, as well as on metabolic processes, which are essential for plant growth and productivity. Regarding to young plants, eventual water restrictions may be determinant for survival, either during seedlings production or at initial development after seedlings transplanting on the definitive site.

Water deficit inhibits cell division and elongation, leading to decrease on plant growth rate. The cell division is affected by enzyme inhibitors and microRNAs which regulate cell division and differentiation (Claeys and Inzé, 2013). The cell elongation is a consequence of cell wall extensibility and turgor pressure, which are gibberelins-signaling dependent. Gibberelins act in proteins synthesis that control the reactive oxygen species levels, regulating the $\mathrm{Ca}^{2+}$ content, which influences the cell wall stiffness and play direct control on its resistance of turgor pressure (Achard et al., 2008; Dupuy et al., 2010).

Water stress also negatively affect growth due to reducing photosynthesis rates, which leads to a decreasing on primary carbohydrate synthesis. Since stomatal closure is among the first physiological events to occur in response to water deficiency, and since stomatal conductance is always strongly correlated with $\mathrm{CO}_{2}$ net assimilation, it is assumed that a reduced stomatal opening reduces $\mathrm{CO}_{2}$ absorption in leaves under water stress (Aroca, 2012). Water stress, on the other hand, induces the reactive oxygen species synthesis, which oxidize chlorophylls, causing damage to the photosynthetic apparatus (Van Breusegem and Dat, 2006). If stress is severe, there may be a decrease on Rubisco activity and difficulty to regenerate RuBP, negatively affecting photosynthesis (Bota et al., 2004).

Cattle manure is an organic fertilizer that, in addition to providing nutrients, can improve other soil chemical and physical attributes by altering its water retention ability. Cattle manure aggregates soil coloids, affecting the porosity (macro, micro and total), density and resistance to root penetration (Tormena et al., 2002; Galvão et al., 2008; Guareschi et al., 2012). The pore size is linked to capillarity and adsorption, which, in turn, are related to water retention. For these reasons, organic matter is considered as one of the factors that influence the water retention and, consequently, the soil water availability (Tuller and Or, 2004).

In addition to the effects on soil attributes, the application of manure may improve conditions for plant growth under water stress. Studies on [Glycine max (L.) Merr.] leaves fertilized with cattle manure showed that the increase in chlorophyll content may be an indication of decreased activity of glutathione peroxidase and superoxide dismutase (Nozari et al., 2013; Taherianfar et al., 2013). Oregano plants (Origanum vulgare L.) submitted to irrigation intervals of up to three weeks showed increases in number of stems, plant propagation, stem diameter, leaf area and fresh and dry plant yield, with increasing levels of cattle manure (Gerami et al., 2016).

This study aimed to investigate the effect of cattle manure on morphophysiological and biochemical changes of Khaya senegalensis young plants submitted to different irrigation intervals in order to better understanding the tolerance mechanisms to eventual water deficit. 


\section{Material and Method}

The experiment was carried out in a greenhouse at the Southwest Bahia State University, in Vitória da Conquista, Bahia, Brazil (14 $\left.53^{\circ} \mathrm{S} 40^{\circ} 48^{\prime} \mathrm{W}\right), 881 \mathrm{~m}$ a.s.l. and Tropical Altitude climate (Cwa), according to Köppen classification. The experimental period lasted from March to August 2017 (cold season), in order to simulate the weather conditions of a typical season with low temperatures and shortage rainfall.

\subsection{Plant Material and Experimental Design}

Khaya senegalensis seedlings 120 days old were produced in $280 \mathrm{~cm}^{3}$ tubes and were transplanted in $20 \mathrm{~L}$ pots, whose substrate was a yellow dystrophic Tb latosol, sandy-clay texture, to which the cattle manure was added and mixed in different proportions.

The experimental design was randomized blocks, arranged in factorial 5x3, three blocks, one plant per replication, totaling 45 plants. One factor was the cattle manure in percentages 0,10 , 20,30 and $40 \%$ of the total volume of the substrate $(16 \mathrm{~L})$. The other factor was the irrigation intervals, that is, 3, 6 and 12 days. At each irrigation, the amount of water supply was equivalent to the difference between the weight of each pot and the average weight of three pots kept permanently close to the field capacity.

\subsection{Water Potential and Relative Water Content}

The plant water status was evaluated based on water potential and relative water content data of mature leaves of the middle part of the canopy, measured at the pre-dawn. For water potential measurements, a pressure chamber (Model 1000, PMS) was used, according to Scholander et al. (1965). For relative water content (RWC) determination, leaf discs were collected, and their fresh (FM), dry (DM) and turgid (TM) masses were checked. RWC was obtained by the formula RWC $=[($ FM-DM) / (TM-DM) $] .100$, according to Weatherley (1950).

\subsection{Water Consumption and Water Use Efficiency}

For water consumption (WC) measurement per plant, the amount of water supplied at each irrigation required to restore the substrate moisture close the field capacity, was considered. The water use efficiency (WUE) determination was obtained by the stem volume (SV) and $\mathrm{WC}$ ratio, that is: $\mathrm{WUE}=\mathrm{SV} / \mathrm{WC}$.

\subsection{Chlorophyll Content Estimation (Spad Index)}

For SPAD index measurements, mature leaves of the middle part of the canopy were chosen, and a SPAD-502 Plus chlorophyllometer (Minolta Corporation, Ltda., Osaka, Japan) was used. Measurements were carried out from 12 a.m. to 1 p.m., and data were assumed as the average of seven measurements per plant.

\subsection{Morphological and Physiological Evaluations}

Plant height and stem diameter were measured by using a tape measure and digital caliper, respectively. After the experimental period, plants were removed from the pots, submitted to kiln-drying, and dry mass was checked. 


\subsection{Biochemical Analysis}

After the experimental period, mature leaves from the middle part of the canopy were collected and submitted to kiln-drying. $15 \mathrm{~mL}$ of potassium phosphate solution $0.1 \mathrm{M}$ were used to aminoacid (total) and proline extraction, from $200 \mathrm{~g}$ of dried leaves. The mixture was filtered and centrifuged at $8,000 \mathrm{rpm}$ for 15 minutes, collecting the supernatant, in a replicated procedure three times, until the final extract was obtained.

For amino acid content determination, the method proposed by Yemm and Coccking (1955) was followed. Aliquots from the extract were added to a medium containing $0.5 \mathrm{~mL}$ of $0.2 \mathrm{M}$ sodium citrate buffer ( $\mathrm{pH} 5.0$ ), $0.2 \mathrm{~mL}$ of $5 \%$ ninhydrin in methyl cellosolve, $1.0 \mathrm{~mL}$ of $2 \%$ $\mathrm{KCN}$, in methyl celosolve and $0.94 \mathrm{~mL}$ of water. At the end, the amino acid content was analyzed by a spectrophotometer at $570 \mathrm{~nm}$.

For proline content determination, the method proposed by Bates et al. (1973) was followed. Aliquots from the extract were added to a medium containing $2.0 \mathrm{~mL}$ of acidic ninhydrin solution, $2.0 \mathrm{~mL}$ of glacial acetic acid and $1.5 \mathrm{~mL}$ of water. The medium was stirred and heated in a $100{ }^{\circ} \mathrm{C}$ water bath, for 1 hour. After cooling to ambient temperature, $4 \mathrm{~mL}$ of toluene was added to the medium, for complete proline extraction, followed by stirring, thereby forming a supernatant. At the end, proline content was analyzed by a spectrophotometer at $520 \mathrm{~nm}$.

\subsection{Statistical Analysis}

Liliefort and Cochran tests were used for data analysis, in terms of normality and homogeneity, respectively. The analysis of variance, followed by the means test, was used to compare the effects of irrigation intervals. Regression analysis was applied to cattle manure doses data. These procedures were performed by using SAEG 9.1 and ASSISTAT programs, edit $7.7 \mathrm{pt}$.

\section{Results and Discussion}

The irrigation intervals had no significant effect on almost all traits, except for WUE. Inversely, the cattle manure doses affected almost all traits, except the water potential. Interaction between the factors had significant effect on RWC, WC, SPAD index and proline content (Table 1). 
Table 1. Analysis of variance and coefficient of variation (CV) of predawn leaf water potential $\left(\Psi_{\mathrm{W}}\right)$, leaf relative water content (RWC), water consumption (WC), water use efficiency (WUE), SPAD index (SPAD), and amino acid (AA) and proline (P) leaf contents in young plants of Khaya senegalensis fertilized with different cattle manure (CM) doses and submitted to three irrigation (I) intervals.

\begin{tabular}{|c|c|c|c|c|c|}
\hline \multirow{2}{*}{$\begin{array}{c}\text { Sources } \\
\text { of } \\
\text { Variation }\end{array}$} & \multirow{2}{*}{$\begin{array}{l}\text { Degrees } \\
\text { of } \\
\text { Freedom }\end{array}$} & \multicolumn{4}{|c|}{ Mean Squares } \\
\hline & & $\Psi_{\mathrm{W}}$ & RWC & WC & WUE \\
\hline$(\mathrm{CM})$ & 4 & 0.01 & $46.29^{* *}$ & $45.78^{* * *}$ & $33780.73^{*}$ \\
\hline $\begin{array}{l}\text { doses } \\
\text { (I) } \\
\text { intervals }\end{array}$ & 2 & 0.02 & 4.85 & 5.75 & $98044.01^{\text {** }}$ \\
\hline $\begin{array}{l}\text { (CM) } x \\
\text { (I) }\end{array}$ & 8 & 0.01 & $20.77^{*}$ & $7.49^{* *}$ & 5057.26 \\
\hline Blocks & 2 & $0.03^{*}$ & 8.55 & $0.01^{*}$ & 291.82 \\
\hline Error & 28 & 0.01 & 8.05 & 1.95 & 8373.17 \\
\hline CV $(\%)$ & & 17.88 & 3.43 & 7.26 & 23.50 \\
\hline $\begin{array}{c}\text { Sources } \\
\text { of } \\
\text { Variation }\end{array}$ & $\begin{array}{l}\text { Degrees } \\
\text { of } \\
\text { Freedom }\end{array}$ & \multicolumn{4}{|c|}{ Mean Squares } \\
\hline & & SPAD & & & $\mathrm{P}$ \\
\hline $\begin{array}{l}(\mathrm{CM}) \\
\text { doses }\end{array}$ & 4 & $107.88^{\text {*** }}$ & & & $0.93^{* * *}$ \\
\hline $\begin{array}{l}\text { (I) } \\
\text { intervals }\end{array}$ & 2 & 4.58 & & & 0.03 \\
\hline $\begin{array}{l}(\mathrm{CM}) \quad \mathrm{x} \\
\text { (I) }\end{array}$ & 8 & $23.11^{* *}$ & & & $0.15^{* *}$ \\
\hline Blocks & 2 & 2.57 & & & 0.01 \\
\hline Error & 28 & 3.67 & & & 0.03 \\
\hline CV (\%) & & 2.99 & & & 15.95 \\
\hline
\end{tabular}

(*) significant $(\mathrm{p} \leq 0.05) ;(* *)$ significant $(\mathrm{p} \leq 0.01)$

Leaf water potential was not affected by both factors. This can be interpreted that there was no significant reduction on substrate water availability, even after the largest irrigation interval. The predawn leaf water potential, besides representing the plant water status, is generally assumed to represent the mean soil water potential next to the roots, being closely corelated to the relative transpiration rate (Améglio et al., 1999; Williams and Araujo, 2002; Chastain et al., 2016).

The fact that there was no water potential change, even after 12-day irrigation interval, can be related to a probable low evapotranspiration rate, due to the meteorological conditions of that period, since the experiment was carried out during the winter, when temperature and solar radiation are reduced.

Field conditions researches on both brazilian mahogany (Swietenia macrophylla) (Morais et al., 2015) and african mahogany (Khaya senegalensis) (Arndt et al., 2015) showed that predawn leaf water potential varies according to the meteorological conditions, since the mean values in dry season (winter) were lower than in rainy season (summer). 
Irrigation intervals had no effect on RWC, which corroborates the understanding that the substrate water availability did not decrease significantly even after the longest irrigation interval. On the other hand, RWC was affected by cattle manure doses, and the interaction between this factor and the irrigation intervals was significant (Table 1).

Cattle manure doses had a quadratic effect on RWC, although this was occurred just on the 12-day irrigation interval. In this irrigation interval, the RWC increased, with increasing cattle manure doses up to the estimated value of $20.87 \%$, followed by a decrease at higher doses (Figure 1). At the shortest irrigation intervals, a regression equation to express the cattle manure effect on RWC became unpracticable. Researchers have reported variable effects of organic manures on leaf RWC in plants under water deficit (Khadem et al., 2010; Rahbarian et al., 2014), but this relationship remains not clear.
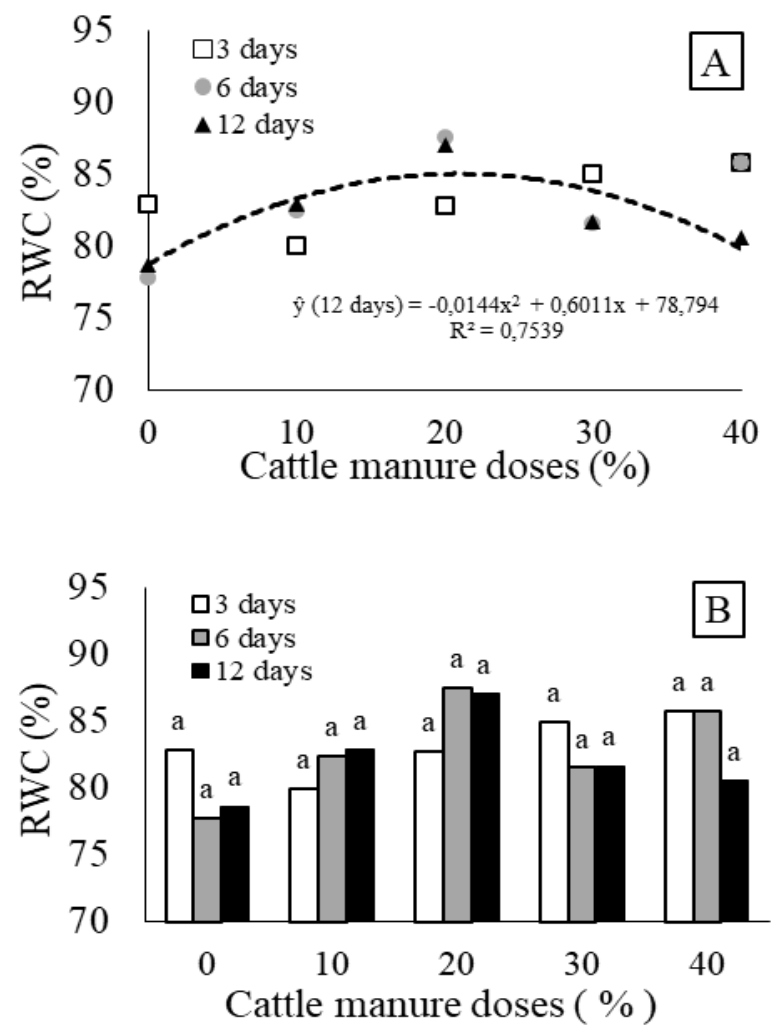

Figure 1. Leaf relative water content (RWC) in young plants of Khaya senegalensis fertilized with different cattle manure doses and submitted to three irrigation intervals. Effect of cattle manure doses on RWC in each irrigation interval [A]. RWC mean values of irrigation intervals, in each cattle manure dose [B]. Within each cattle manure dose, RWC mean values having the same letters indicate that there is no significant difference among the irrigation intervals. Mean values were compared by Tukey's test $(\mathrm{p} \leq 0.05)$

Irrigation intervals had no significant effect on WC. However, it was affected by the cattle manure doses, and there was significant interaction between this factor and the irrigation intervals (Table 1). WC was slightly lower, with increasing cattle manure doses (Figure 2A). In plants fertilized with $30 \%$ cattle manure, $\mathrm{WC}$ in the 12-day irrigation interval was lower than in the shorter irrigation intervals (Figure 2B). 

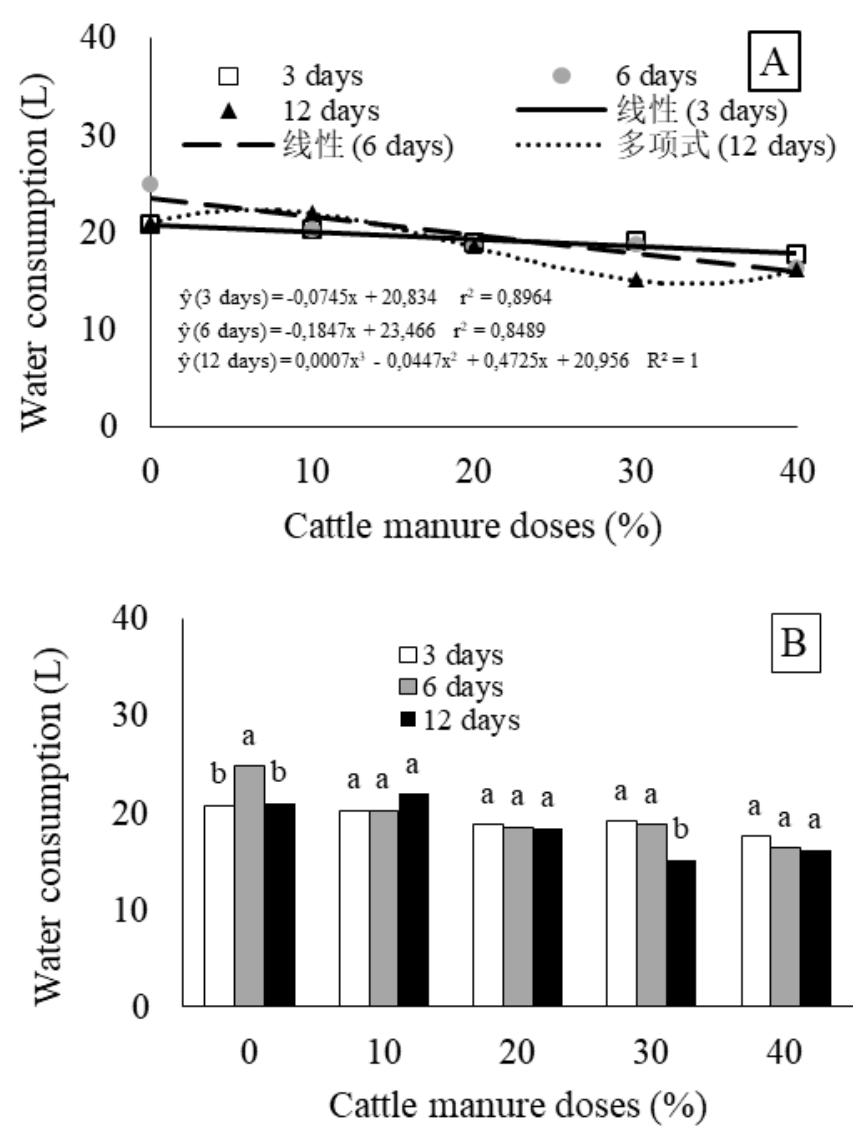

Figure 2. Water consumption in plant-soil system, in which young plants of Khaya senegalensis were fertilized with different cattle manure doses and submitted to three irrigation intervals. Effect of cattle manure doses on water consumption in each irrigation interval [A]. Water consumption mean values of irrigation intervals, in each cattle manure dose [B]. Within each cattle manure dose, water consumption mean values having the same letters indicate no significant difference among the irrigation intervals. Mean values were compared by Tukey's test ( $\mathrm{p} \leq 0.05)$

Changes on WC can be attributed to the beneficial effects of manure fertilization on soil physical properties. With the addition of organic matter, the soil specific surface area increases resulting in increased water holding capacity at higher tensions (Haynes and Naydu, 1998; Vengadaramana and Thairiyanathan, 2012).

Both cattle manure doses and irrigation intervals had significant effect on WUE. Nevertheless, there was no significant interaction between these factors (Table 1). Increasing cattle manure doses led to a greater WUE (Figure 3A). There was no difference on WUE between 3-day and 6-day irrigation intervals, but WUE was higher in the 12-day irrigation interval (Figure 3B). 

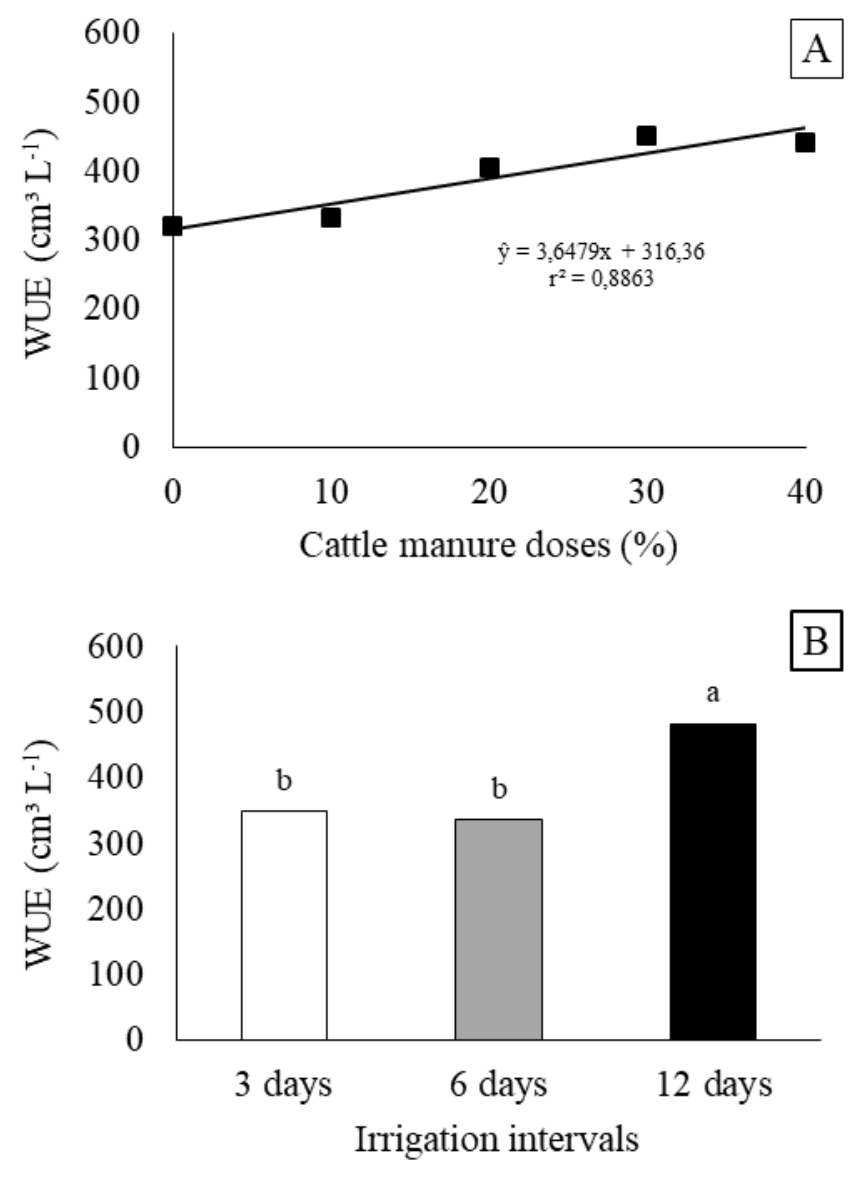

Figure 3. Water use efficiency (WUE) in young plants of Khaya senegalensis fertilized with different cattle manure doses and submitted to three irrigation intervals. Effect of cattle manure doses on WUE [A]. Effect of irrigation intervals on WUE [B]. WUE mean values having the same letters above the columns indicate no significant difference among the irrigation intervals. Mean values were compared by Tukey's test $(\mathrm{p} \leq 0.05)$

Previous studies have shown that organic fertilizers application can increase the soil water-holding capacity and improving WUE (Fan et al., 2005; Wang et al., 2017; Zhang et al., 2017). Liu et al. (2013) found that organic fertilizer increased the soil water-holding capacity by increasing the percentage of macro-aggregates $(>0.25 \mathrm{~mm}$ ) and soil nutrients, which ultimately improved WUE. As for the increased water use efficiency under 12-day irrigation interval, this physiological response has been attributed by some researchers to a decreased stomatal conductance more pronounced than carbon assimilation, which results in greater instant water use efficiency (Pita et al., 2005; Perez et al., 2016), as well as to a decreased water deep percolation and evaporation (Gholamhoseini et al., 2013).

Irrigation intervals had no effect on SPAD index. On the other hand, SPAD index was affected by cattle manure doses, and there was significant interaction between this factor and irrigation intervals (Table 1). Increasing cattle manure doses increased SPAD index, irrespective of irrigation intervals (Figure 4). This is similar to the findings of a number of researchers (Njoku et al., 2008; Jahromi et al., 2012; Yamika et al., 2018), who observed higher chlorophyll levels in plants under organic fertilization than in no fertilized plants. 

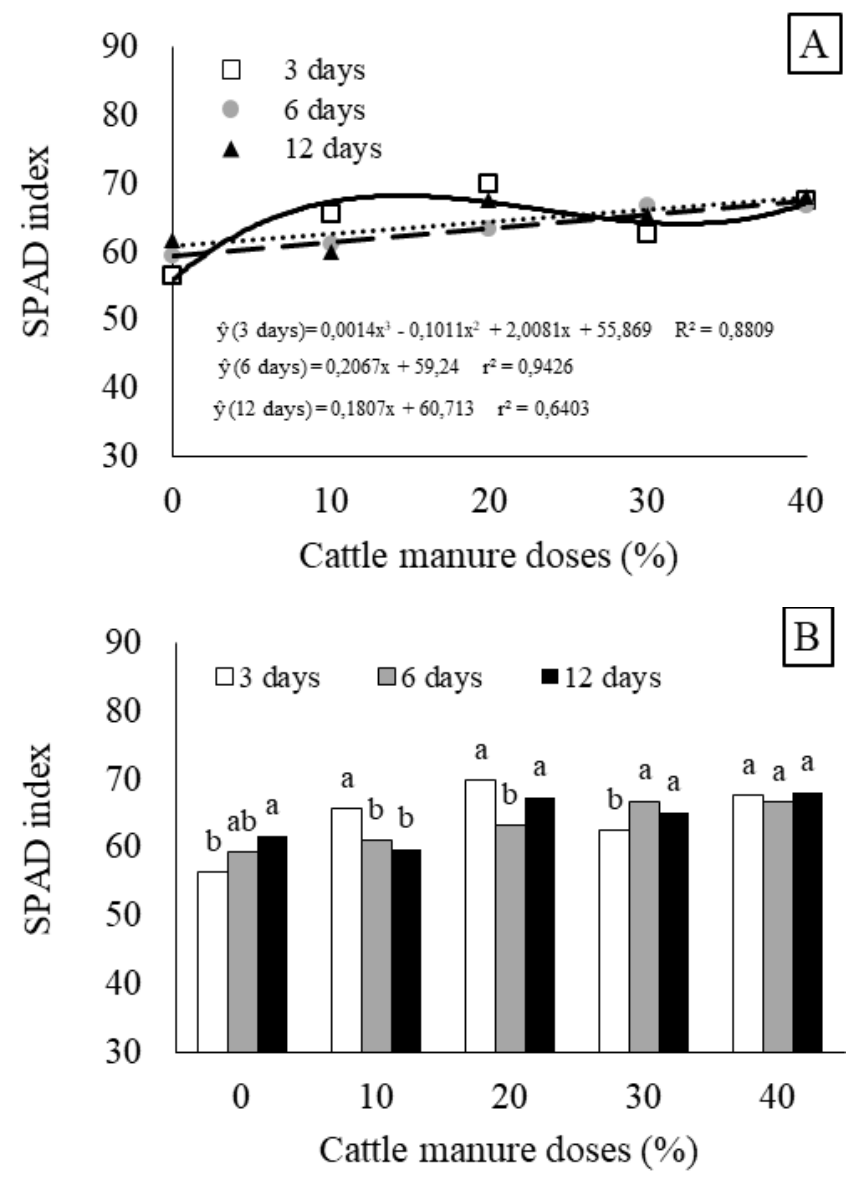

Figure 4. Leaf chlorophyll content estimation (SPAD index) in young plants of Khaya senegalensis fertilized with different cattle manure doses and submitted to three irrigation intervals. Effect of cattle manure doses on SPAD index in each irrigation interval [A]. SPAD index mean values of irrigation intervals, in each cattle manure dose [B]. Within each cattle manure dose, SPAD index mean values having the same letters indicate no significant difference among the irrigation intervals. Mean values were compared by Tukey's test $(\mathrm{p} \leq$ $0.05)$

Increasing SPAD index related to increased cattle manure doses was probably due to the role of organic matter in improving availability of soil nutrients that can be absorbed by Khaya senegalensis young plants. Decreasing leaf chlorophyll content in plants under limited water supply is well known (Aroca, 2012). Thus, the greater values of SPAD index, related to increasing doses of cattle manure, are assumed to be important because they signal to a possible mitigation of the negative effects of water stress, since the photosynthetic activity and carbohydrate yield increase with increased leaf chlorophyll content (Ramesh et al., 2002).

Irrigation intervals had no effect on free amino acid content in leaf tissues. Nevertheless, amino acids were affected by cattle manure doses, although there was no significant interaction between this factor and irrigation intervals (Table 1). Increasing cattle manure doses increased amino acid content, irrespective of irrigation intervals (Figure 5). Similar results were previously reported by Abou El-Khair et al. (2011), and this is probably due to 


\section{Macrothink}

Journal of Agricultural Studies

ISSN 2166-0379 2020, Vol. 8, No. 1

the known cattle manure effect on improving availability of soil nutrients, specially the nitrogen (Haynes and Naydu, 1998).

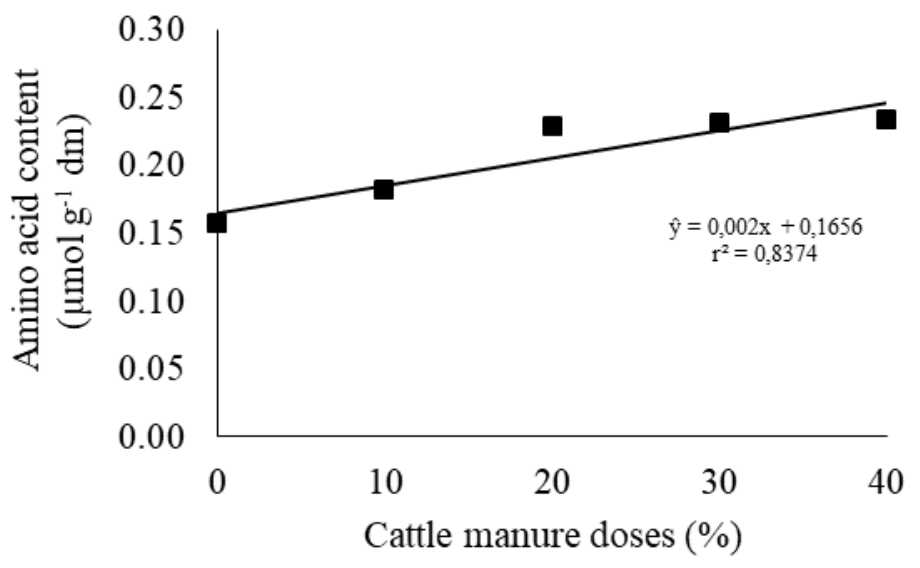

Figure 5. Cattle manure effect on leaf amino acid content in young plants of Khaya senegalensis fertilized with different cattle manure doses and submitted to three irrigation intervals. Data were transformed using $\sqrt{ }(x)$, to attain a normal distribution, according to the

\section{Lilliefort test}

Irrigation intervals had no effect on proline content. On the other hand, proline was affected by cattle manure doses, and there was significant interaction between this factor and irrigation intervals (Table 1). Cattle manure effect was similar to that on total amino acids, this is, a positive correlation between increasing doses and proline content (Figure 6A). Nevertheless, there was no standard response among the irrigation intervals on each cattle manure dose (Figure 6B). 

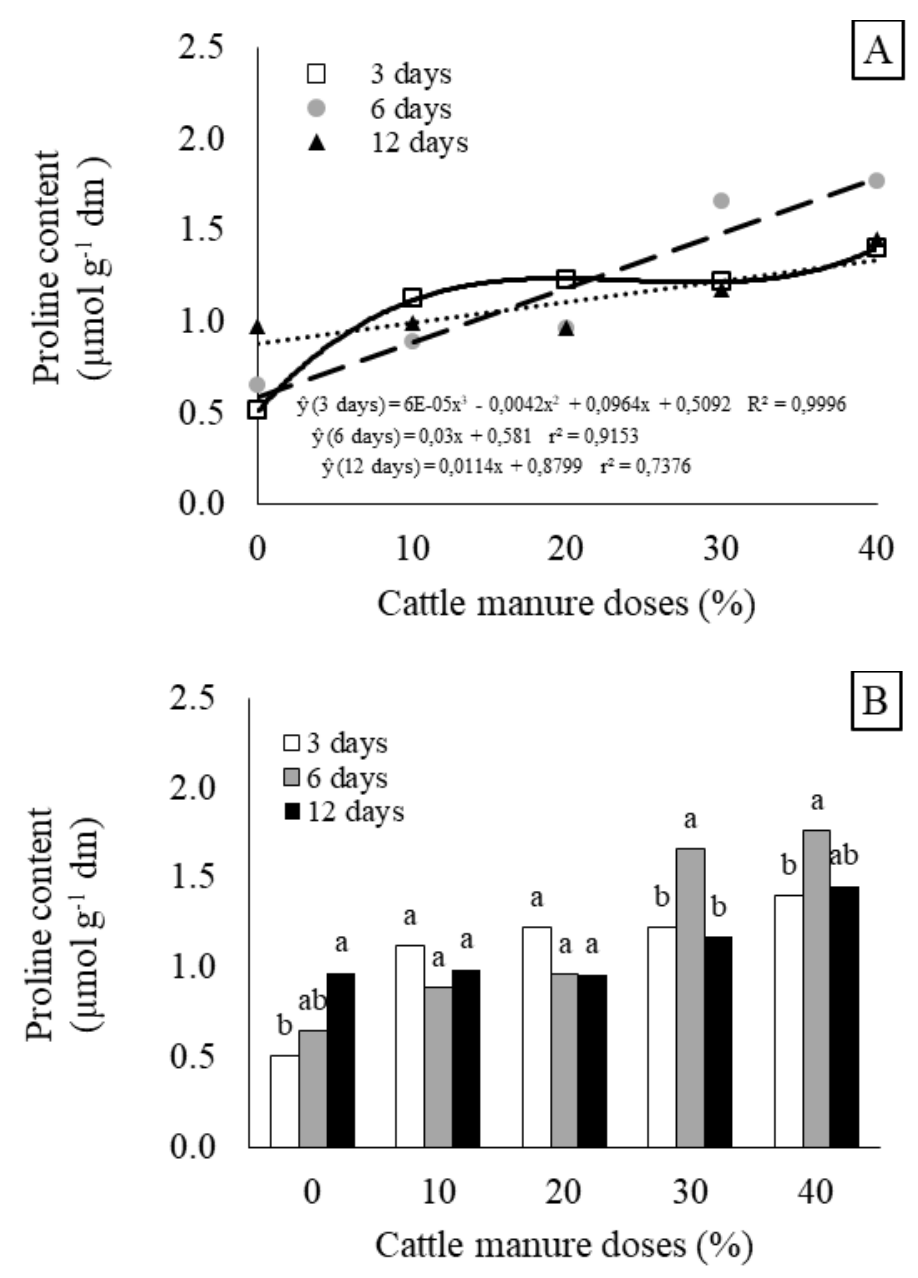

Figure 6. Cattle manure effect on leaf proline content in young plants of Khaya senegalensis fertilized with different cattle manure doses and submitted to three irrigation intervals. Effect of cattle manure doses on proline content in each irrigation interval [A]. Proline content mean values of irrigation intervals, in each cattle manure dose [B]. Within each cattle manure dose, proline content mean values having the same letters indicate no significant difference among the irrigation intervals. Data were transformed using $\log (x)$, to attain a normal distribution, according to the Lilliefort test. Mean values were compared by Tukey's test $(p \leq 0.05)$

Cattle manure had no significant effect on growth parameters. Nevertheless, irrigation intervals reflected significant differences on plant height, stem diameter and total dry mass (Table 2). All growth parameters were positively correlated with irrigation intervals. In general, the mean values of these parameters were higher in plants under a 12-day irrigation interval, with little or no difference between the 3-day and 6-day irrigation intervals (Figures 7 and 8$)$. 


\section{Macrothink}

Journal of Agricultural Studies

ISSN 2166-0379 2020, Vol. 8, No. 1

Table 2. Analysis of variance and coefficient of variation (CV) of plant height, stem diameter and total dry mass in young plants of Khaya senegalensis fertilized with different cattle manure $(\mathrm{CM})$ doses and submitted to three irrigation (I) intervals

\begin{tabular}{|c|c|c|c|c|}
\hline \multirow{2}{*}{$\begin{array}{l}\text { Sources of } \\
\text { Variation }\end{array}$} & \multirow{2}{*}{$\begin{array}{l}\text { Degrees } \\
\text { of } \\
\text { Freedom }\end{array}$} & \multicolumn{3}{|c|}{ Mean Squares } \\
\hline & & $\begin{array}{l}\text { Plant } \\
\text { height }\end{array}$ & $\begin{array}{c}\text { Stem } \\
\text { diameter }\end{array}$ & $\begin{array}{c}\text { Total } \\
\text { dry mass }\end{array}$ \\
\hline $\begin{array}{l}(\mathrm{CM}) \\
\text { doses }\end{array}$ & 4 & 9.45 & 2.17 & 190.57 \\
\hline $\begin{array}{l}\text { (I) } \\
\text { intervals }\end{array}$ & 2 & $349.27^{* *}$ & $8.05^{*}$ & $1046.72^{* *}$ \\
\hline $\begin{array}{l}\mathrm{CM} \times \mathrm{I} \\
\text { interation }\end{array}$ & 8 & 24.98 & 1.29 & 228.51 \\
\hline Blocks & 2 & $0.54^{*}$ & 0.64 & 37.54 \\
\hline Error & 28 & 36.89 & 2.32 & 130.25 \\
\hline $\mathrm{CV}(\%)$ & & 11.45 & 9.70 & 24.10 \\
\hline
\end{tabular}

(*) F significant $(\mathrm{p} \leq 0.05) ;(* *)$ F significant $(\mathrm{p} \leq 0.01)$ 

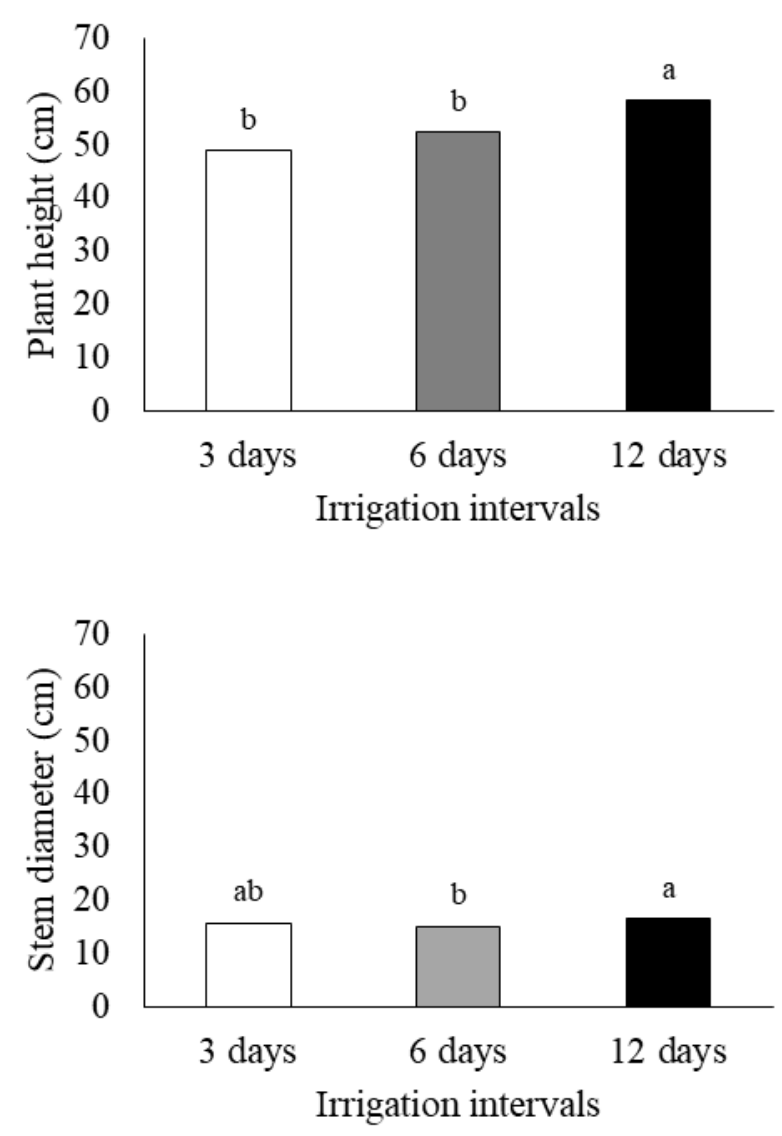

Figure 7. Irrigation intervals effect on plant height and stem diameter in young plants of Khaya senegalensis fertilized with different cattle manure doses. Mean values having the same letters above the columns indicate no significant difference among the irrigation intervals. Mean values were compared by Tukey's test $(\mathrm{p} \leq 0.05)$

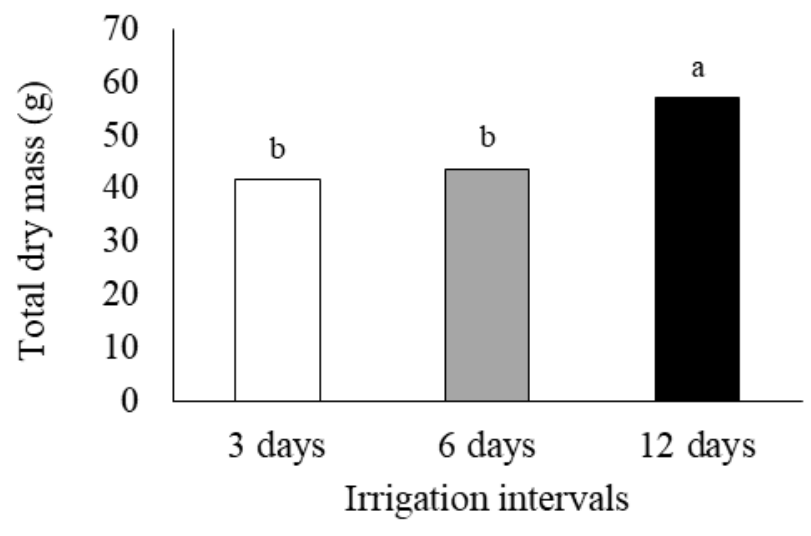

Figure 8. Irrigation intervals effect on total dry mass in young plants of Khaya senegalensis fertilized with different cattle manure doses. Mean values having the same letters above the columns indicate no significant difference among the irrigation intervals. Mean values were compared by Tukey's test $(\mathrm{p} \leq 0.05)$

In general, growth-related parameters, such as plant height, stem diameter and dry mass 
accumulation, tend to be negatively affected by longer irrigation intervals, given the less frequent water supply (Bagheri et al., 2012; Asadi and Alimohamadi, 2019). In this study, however, lower values of plant height and total dry mass were found in 3-day and 6-day irrigation intervals, compared to 12-day interval.

We suspect some factors that may have influenced these performances on growth-related parameters. First, a supposedly low evapotranspiration, given the winter mean temperatures $\left(14-16^{\circ} \mathrm{C}\right)$, may have reduced the demand for irrigation in the experimental period. No difference in water potential among the irrigation intervals corroborates an indication that there was no soil water deficit. Thus, both in 3-day and 6-day irrigation interval, soil moisture may have increased until reach to a close to saturation level. This could create a condition which greatly limits the amount of oxygen roots can obtain and hampers nutrient uptake.

The biology of plant tolerance to saturated soils is still poorly understood, and studies conducted to determine flood tolerance have resulted in contradictory conclusions. Still, it is generally accepted a decline in growth as an usual plant response to saturated soils. Restricted tree and root growth was observed when air capacity was reduced to level less than $15 \%(\mathrm{Nel}$ and Bennie, 1984). Soil saturation up to close to flooding negativelly affecting growth-related parameters in tree species has also been reported (Sakio, 2005; Oliveira and Joly, 2010; Allen et al., 2019).

\section{Conclusion}

Irrigation intervals had no significant effect on both physiological traits and plant water relationships, except for WUE, which was higher under 12-day irrigation interval. This was assumed as an indication of non-occurrence of water stress, even under the longest irrigation interval. Cattle manure, in turn, had a significant effect on these traits, except for water potential, irrespective of irrigation intervals. Increasing cattle manure doses improved RWC (just doses up to 20\%), reduced WC and increased WUE, SPAD index, and both free amino acid and proline contents. On the other hand, growth-related parameters were not affected by cattle manure, but a significant effect of irrigation intervals was observed. Both plant height and total dry mass were lower under 3-day and 6-day irrigation intervals. A probable reduced demand for irrigation during experimental period may have occurred, related to a possible low evapotranspiration, given the relatively low temperatures of that season $\left(14-16^{\circ} \mathrm{C}\right)$. We suspect that shorter irrigation intervals may have increased the soil moisture until reach to a close to saturation level, limiting the amount of soil oxygen and hampering the nutrient uptake.

\section{References}

Abou El-Khair, E. E., Nawar, D. A. S., \& Ismail, H. M. E. (2011). Effect of irrigation water quantity and farmyard manure on potato plant grown in sandy soil. Egyptian Journal of Agricultural Research, 89(1), 317-334.

Achard, P., Renou, J. P., Berthomé, R., Harberd, N. P., \& Genschik, P. (2008). Plant DELLAs restrain growth and promote survival of adversity by reducing the levels of reactive oxygen species. Current Biology, 18(9), 656-660. https://doi.org/10.1016/j.cub.2008.04.034 
Allen, S. T., Keim, R. F., \& Dean, T. J. (2019). Contrasting effects of flooding on tree growth and stand density determine aboveground production, in baldcypress forests. Forest Ecology and Management, 432, 345-355. https://doi.org/10.1016/j.foreco.2018.09.041

Améglio, T., Archer, P., Cohen, M., Valancogne, C., Daudet, F. A., Dayau, S., \& Cruiziat, P. (1999). Significance and limits in the use of predawn leaf water potential for tree irrigation. Plant and Soil, 207(2), 155-167. https://doi.org/10.1023/A:1026415302759

Arndt, S. K., Sanders, G. J., Bristow, M., Hutley, L. B., Beringer, J., \& Livesley, S. J. (2015). Vulnerability of native savanna trees and exotic Khaya senegalensis to seasonal drought. Tree Physiology, 35(7), 783-791. https://doi.org/10.1093/treephys/tpv037

Aroca, R. (2012). Plant responses to drought stress. From morphological to molecular features. Berlin: Springer-Verlag. p. 466. https://doi.org/10.1007/978-3-642-32653-0

Asadi, F., \& Alimohamadi, A. (2019). Assessing the performance of Populus caspica and Populus alba cuttings under different irrigation intervals. Agriculture \& Forestry, 65(2), 39-51. https://doi.org/10.17707/AgricultForest.65.2.03

Bagheri, R., Ghasemi, R., Calagari, M., \& Merrikh, F. (2012). Effects of different irrigation intervals on superior poplar clones yield. Iranian Journal of Forests and Poplar Research, 20(3), 357-369.

Bates, L. S., Waldren, R. P., \& Teare, I. D. (1973). Rapid determination of free proline for water stress studies. Plant and Soil, 39(1), 205-207. https://doi.org/10.1007/BF00018060

Bota, J., Medrano, H., \& Flexas, J. (2004). Is photosynthesis limited by decreased Rubisco activity and RuBP content under progressive water stress? New Phytologist, 162(3), 671-681. https://doi.org/10.1111/j.1469-8137.2004.01056.x

Chastain, D. R., Snider, J. L., Collins, G. D., Perry, C. D., Whitaker, J., Byrd, S. A., .. Porter, W. M. (2016). Irrigation scheduling using predawn leaf water potential improves water productivity in drip-irrigated cotton. Crop Science, 56(6), 3185-3195. https://doi.org/10.2135/cropsci2016.01.0009

Claeys, H., \& Inzé, D. (2013). The agony of choice: how plants balance growth and survival under water-limiting conditions. Plant Physiology, 162(4), 1768-1779.

https://doi.org/10.1104/pp.113.220921

Dupuy, L., Mackenzie, J., \& Haseloff, J. (2010). Coordination of plant cell division and expansion in a simple morphogenetic system. Proceedings of the National Academy of Sciences, 107(6), 2711-2716. https://doi.org/10.1073/pnas.0906322107

Fan, T., Stewart, B. A., Yong, W., Junjie, L., \& Guangye, Z. (2005). Long-term fertilization effects on grain yield, water-use efficiency and soil fertility in the dryland of Loess Plateau in China. Agriculture, Ecosystems \& Environment, 106(4), 313-329. https://doi.org/10.1016/j.agee.2004.09.003

Galvão, S. R. S., Salcedo, I. H., \& Oliveira, F. F. (2008). Acumulação de nutrientes em solos 
arenosos adubados com esterco bovino. Pesquisa Agropecuária Brasileira, 43(1), 99-105. https://doi.org/10.1590/S0100-204X2008000100013

Gerami, F., Moghaddam, P. R., Ghorbani, R., \& Hassani, A. (2016). Effects of irrigation intervals and organic manure on morphological traits, essential oil content and yield of oregano (Origanum vulgare L.). Anais da Academia Brasileira de Ciências, 88(4), 2375-2385. https://doi.org/10.1590/0001-3765201620160208

Gholamhoseini, M., Ghalavand, A., Khodaei-Joghan, A., Dolatabadian, A., Zakikhani, H., \& Farmanbar, E. (2013). Zeolite-amended cattle manure effects on sunflower yield, seed quality, water use efficiency and nutrient leaching. Soil and Tillage Research, 126, 193-202. https://doi.org/10.1016/j.still.2012.08.002

Guareschi, R. F., Pereira, M. G., \& Perin, A. (2012). Deposição de resíduos vegetais, matéria orgânica leve, estoques de carbono e nitrogênio e fósforo remanescente sob diferentes sistemas de manejo no cerrado Goiano. Revista Brasileira de Ciência do Solo, 36(3), 909-920. https://doi.org/10.1590/S0100-06832012000300021

Haynes, R. J., \& Naidu, R. (1998). Influence of lime, fertilizer and manure applications on soil organic matter content and soil physical conditions: a review. Nutrient Cycling in Agroecosystems, 51(2), 123-137. https://doi.org/10.1023/A:1009738307837

Jahromi, M. G., Aboutalebi, A., \& Farahi, M. H. (2012). Influence of different levels of garden compost (garden wastes and cow manure) on growth and stand establishment of tomato and cucumber in greenhouse condition. African Journal of Biotechnology, 11(37), 9036-9039. https://doi.org/10.5897/AJB11.4139

Khadem, S. A., Galavi, M., Ramrodi, M., Mousavi, S. R., Rousta, M. J., \& Rezvani-Moghadam, P. (2010). Effect of animal manure and superabsorbent polymer on corn leaf relative water content, cell membrane stability and leaf chlorophyll content under dry condition. Australian Journal of Crop Science, 4(8), 642-647.

Liu, C. A., Li, F. R., Zhou, L. M., Zhang, R. H., Jia, Y., Lin, S. L., ... Li, F. M. (2013). Effect of organic manure and fertilizer on soil water and crop yields in newly-built terraces with loess soils in a semi-arid environment. Agricultural Water Management, 117, 123-132. https://doi.org/10.1016/j.agwat.2012.11.002

Morais, R. R., Gonçalves, J. F. C., Costa, J. R., \& Ribeiro, G. O. (2015). Curso diário e sazonal do potencial hídrico foliar de mogno em sistema agroflorestal. Revista Árvore, 39(6), 1103-1110. https://doi.org/10.1590/0100-67622015000600013

Nel, D. J., \& Bennie, A. T. P. (1984). Soil factors affecting tree growth and root development in a citrus orchard. South African Journal of Plant and Soil, 1(2), 39-47. https://doi.org/10.1080/02571862.1984.10634107

Nikiema, A., \& Pasternak, D. (2008). Khaya senegalensis (Desr.) A. Juss. In D. Louppe, A. A. Oteng-Amoako, \& M. Brink (Eds.), Plant resources of tropical Africa (PROTA) (pp. 339-344). Wageningen: Netherlands. 
Njoku, K., Akinola, M., \& Oboh, B. (2008). Growth and performance of Glycine max L. (Merrill) grown in crude oil contaminated soil augmented with cow dung. Life Science Journal, 5(3), 89-93.

Nozari, R., Tohidi, M. H. R., \& Zahedi, H. (2013). Effect of cattle manure and zeolite applications on physiological and biochemical changes in soybean [Glycine max (L.) Merr.] grown under water deficit stress. Revista Científica UDO Agrícola, 13(1), 76-84. https://doi:10.13140/RG.2.1.4409.2648

Oliveira, V. C., \& Joly, C. A. (2010). Flooding tolerance of Calophyllum brasiliense Camb. (Clusiaceae): morphological, physiological and growth responses. Trees, 24(1), 185-193. https://doi.org/10.1007/s00468-009-0392-2

Perez, B. A. P., Valeri, S. V., Cruz, M. C. P., \& Vasconcelos, R. T. (2016). Potassium doses for African mahogany plants growth under two hydric conditions. African Journal of Agricultural Research, 11(22), 1973-1979. https://doi.org/10.5897/AJAR2016.11026

Pinheiro, A. L., Couto, L., Pinheiro, D. T., \& Brunetta, J. M. F. C. (2011). Ecologia, silvicultura e tecnologia de utilização dos mognos-africanos (Khaya spp.). Viçosa: Sociedade Brasileira de Agrossilvicultura. p 102.

Pita, P., Cañas, I., Soria, F., Ruiz, F., \& Toval, G. (2005). Use of physiological traits in tree breeding for improved yield in drought-prone environments. The case of Eucalyptus globulus. Investigación Agraria. Sistemas y Recursos Forestales, 14(3), 383-393. https://doi.org/10.5424/srf/2005143-00931

Rahbarian, P., Sardoei, A. S., Gholamshahi, S., \& Khorshidi, G. (2014). Relative water content, cell membrane stability, essential oil and morphology of Dracocphalum moldavica L. are influenced by drought stress and manure. International Journal of Biosciences, 5(1), 421-428. https://doi.org/10.12692/ijb/5.1.421-428

Ramesh, K., Chandrasekaran, B., Balasubramanian, T. N., Bangarusamy, U., Sivasamy, R., \& Sankaran, N. (2002). Chlorophyll dynamics in rice (Oryza sativa) before and after flowering based on SPAD (chlorophyll) meter monitoring and its relation with grain yield. Journal of Agronomy and Crop Science, 188(2), 102-105.

https://doi.org/10.1046/j.1439-037X.2002.00532.x

Sakio, H. (2005). Effects of flooding on growth of seedlings of woody riparian species. Journal of Forest Research, 10(4), 341-346. https://doi.org/10.1007/s10310-005-0156-9

Scholander, P. F., Bradstreet, E. D., Hemmingsen, E. A., \& Hammel, H. T. (1965). Sap pressure in vascular plants. Science, 148(3668), 339-346.

https://doi.org/10.1126/science.148.3668.339

Taherianfar, A., Tohidi, M. H. R., \& Zahedi, H. (2013). Effect of cattle manure and mycorrhiza applications on physiological and biochemical changes in soybean [Glycine max (L.) Merr.] grown under water deficit stress. Revista Científica UDO Agrícola, 13(1), 85-92. https://doi:10.13140/RG.2.1.1787.8240 


\section{$\triangle$ Macrothink}

Tormena, C. A., Barbosa, M. C., Costa, A. C. S., \& Gonçalves, A. C. A. (2002). Densidade, porosidade e resistência à penetração em Latossolo cultivado sob diferentes sistemas de preparo do solo. Scientia Agricola, 59(4), 795-801.

https://doi.org/10.1590/S0103-90162002000400026

Tuller, M., \& Or, D. (2004). Retention of water in soil and the soil water characteristic curve. Encyclopedia of Soils in the Environment, 4, 278-289.

https://doi.org/10.1016/B0-12-348530-4/00376-3

Van Breusegem, F., \& Dat, J. F. (2006). Reactive oxygen species in plant cell death. Plant Physiology, 141(2), 384-390. https://doi.org/10.1104/pp.106.078295

Vengadaramana, A., \& Thairiyanathan, J. J. P. (2012). Effect of organic fertilizers on the water holding capacity of soil in different terrains of Jaffna peninsula in Sri Lanka. Journal of Natural Product and Plant Resources, 2(4), 500-503.

Wang, L., Wang, S., Chen, W., Li, H., \& Deng, X. (2017). Physiological mechanisms contributing to increased water-use efficiency in winter wheat under organic fertilization. Plos One, 12(6), 1-21. https://doi.org/10.1371/journal.pone.0180205

Weatherley, P. E. (1950). Studies in the water relations of the cotton plant. I - The field measurements of water deficits in leaves. New Phytologist, 49(1), 81-97.

https://doi.org/10.1111/j.1469-8137.1950.tb05146.x

Williams, L. E., \& Araujo, F. J. (2002). Correlations among predawn leaf, midday leaf, and midday stem water potential and their correlations with other measures of soil and plant water status in Vitis vinifera. Journal of the American Society for Horticultural Science, 127(3), 448-454. https://doi.org/10.21273/JASHS.127.3.448

Yamika, W. S. D., Aini, N., Setiawan, A., \& Purwaningrahayu, R. D. (2018). Effect of gypsum and cow manure on yield, proline content, and $\mathrm{K} / \mathrm{Na}$ ratio of soybean genotypes under saline conditions. Journal of Degraded and Mining Lands Management, 5(2), 1047-1053. https://doi.org/10.15243/jdmlm.2018.052.1047

Yemm, E. W., \& Cocking, E. C. (1955). The determination of amino-acids with ninhydrin. Analyst, 80, 209-213. https://doi.org/10.1039/an9558000209

Zhang, H., Yu, X., Jin, Z., Zheng, W., Zhai, B., \& Li, Z. (2017). Improving grain yield and water use efficiency of winter wheat through a combination of manure and chemical nitrogen fertilizer on the Loess plateau, China. Journal of Soil Science and Plant Nutrition, 17(2), 461-474. https://doi.org/10.4067/S0718-95162017005000033

\section{Copyright Disclaimer}

Copyright for this article is retained by the author(s), with first publication rights granted to the journal.

This is an open-access article distributed under the terms and conditions of the Creative Commons Attribution license (http://creativecommons.org/licenses/by/4.0/). 